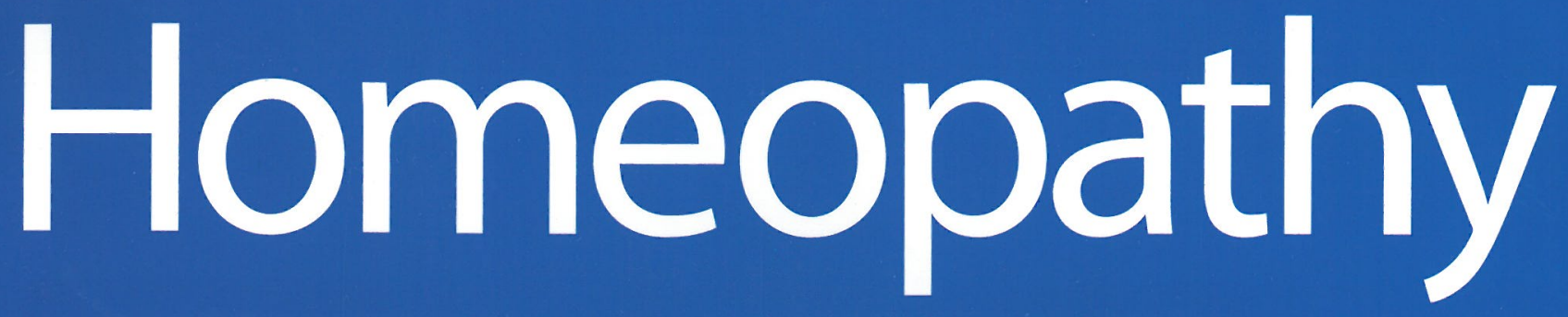

The Journal of the Faculty of Homeopathy

Volume $97 \cdot$ Number 3

- Patient-reported outcomes

- Botanical systematics

- Electrical properties of high dilutions

- Delayed luminescence of high dilutions
- Chamomilla in stress and depression

- Helminth parasitism in sheep

- Untangling the debate

- Hahnemann's values

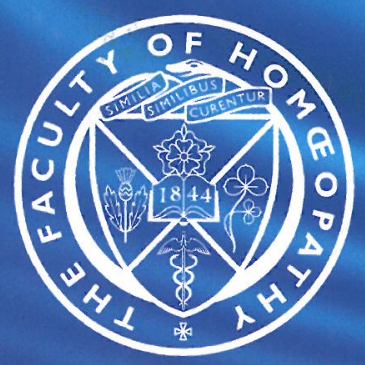


Bob Leckridge

MB ChB FFHom

Cees Baas

Toronto, Canada

Iris R Bell

The University of Arizona, USA

Philippe Belon

Institut Boiron, France

Zvi Bentwich

Rosetta Genomics, Israel

Brian Berman

University of Maryland, School of

Medicine, USA

Martien Brands

University of Liverpool, UK

Michael Carlston

University of California, Santa Rosa,

USA

Diwan Vijay Chand

National Centre for Homoeopathy,

India

Martin Chaplin

London South Bank University, UK

Flávio Dantas

University of Uberlandia, Brazil

Jonathan Davidson

Duke University, USA

Christopher Day

Veterinary Dean,

Faculty of Homeopathy, UK

Jean-Louis Demangeat

Haguenau Hospital, France

Christian Endler

Interuniversity College Graz/Castle of

Seggau, Austria

\section{Editor}

Peter Fisher

FRCP FFHom

London, UK

\section{Editorial Board}

Robert T Mathie

BSc (Hons), PhD

\section{Editorial Advisory Board}

Madeleine Ennis

Queen's University Belfast, Ireland

Edzard Ernst

Universities of Exeter and Plymouth, UK

Edoardo Felisi

CISDO, Milan, Italy

Trevor Gibbs

Bute Medical School, Scotland

Robert Gilchrist

London Metropolitan University, UK

German Guajardo-Bernal

University of Baja California, Mexico

Jennifer Jacobs

University of Washington, USA

Wayne Jonas

Samueli Institute, Alexandria, USA

Steven Kayne

Glasgow Homoeopathic Hospital, UK

David Lilley

Pretoria, South Africa

Klaus Linde

Technical University, Munich, Germany

Menachem Oberbaum

Shaare Zedek Medical Centre, Israel

David Peters

University of Westminster, London, UK

Bernard Poitevin

Association Française pour la

Recherche en Homeopathie, France
DP Rastogi

Central Council for Research

in Homoeopathy, India

David Reilly

Glasgow Homoeopathic Hospital, UK

David Riley

University of New Mexico Medical

School, USA

Jurgen Schulte

University of Technology, Sydney,

Australia

Trevor Thompson

University of Bristol, UK

Andre Thurneysen

KIKOM, Bern, Switzerland

Robbert van Haselen

London, UK

Michel van Wassenhoven

European Committee for Homoeopathy, Belgium

Peter Varley

Homeopathic Dentist, Melbourne,

Australia

Harald Walach

University of Northampton, UK

Fred Wiegant

University of Utrecht, The Netherlands 
Aims and Scope Homeopathy is published quarterly. It is an international journal aimed at improving the understanding and clinical practice of homeopathy by publishing high quality articles on clinical and basic research, clinical audit, evidence-based practice of homeopathy and reflective case reports. It also promotes debate and reviews the homeopathic literature.

This journal is indexed by Index Medicus/MEDLINE, Excerpta Medica, EMBASE, AMEDS CISCOM and CINAHL.

\section{Editorial}

Manuscripts and all editorial correspondence should be sent to the Editor:

Dr Peter Fisher

Homeopathy

Faculty of Homeopathy

Hahnemann House

29 Park Street West

Luton, Bedfordshire, LU1 3BE, UK

Email: journal@trusthomeopathy.org

Sharon Clark: Publication Coordinator

Sarah Buckingham: Editorial Assistant

Manuscripts should be submitted to http://ees.elsevier.com/homp/

\section{(C) 2008 The Faculty of Homeopathy}

This journal and the individual contributions contained in it are protected under copyright by Elsevier Ltd and the following terms and conditions apply to their use:

\section{Photocopying}

Single photocopies of single articles may be made for personal use as allowed by national copyright laws. Permission of the Publisher and payment of a fee is required for all other photocopying, including multiple or systematic copying, copying for advertising or promotional purposes, resale, and all forms of document delivery. Special rates are available for educational institutions that wish to make photocopies for non-profit educational classroom use.

For information on how to seek permission visit www. elsevier.com/permissions or call: (+44) 1865843830 (UK) / (+1) 2152393804 (USA).

\section{Derivative Works}

Subscribers may reproduce tables of contents or prepare lists of articles including abstracts for internal circulation within their institutions. Permission of the Publisher is required for resale or distribution outside the institution. Permission of the Publisher is required for all other derivative works, including compilations and translations (please consult www.elsevier.com/permissions).

\section{Electronic Storage or Usage}

Permission of the Publisher is required to store or use electronically any material contained in this journal, including any article or part of an article (please consult www.elsevier.com/permissions).

Except as outlined above, no part of this publication may be reproduced, stored in a retrieval system or transmitted in any form or by any means, electronic, mechanical, photocopying, recording or otherwise, without prior written permission of the Publisher.

\section{Notice}

No responsibility is assumed by the Publisher for any injury and/or damage to persons or property as a matter of products liability, negligence or otherwise, or from any use or operation of any methods, products, instructions or ideas contained in the material herein. Because of rapid advances in the medical sciences, in particular, independent verification of diagnoses and drug dosages should be made.

Although all advertising material is expected to conform to ethical (medical) standards, inclusion in this publication does not constitute a guarantee or endorsement of the quality or value of such product or of the claims made of it by its manufacturer.
Orders, claims, and journal enquiries: please contact the Regional Sales Office nearest you:

Orlando: Elsevier, Customer Service Department, 6277 Sea Harbor Drive, Orlando, FL 32887-4800, USA; phone: (800) 6542452 [toll free within the USA]; fax: (407) 3639661; phone (+1) (407) 5636020 [outside the USA]; fax: (+1) (407) 3631354; e-mail: JournalCustomerService-usa@ elsevier.com

Amsterdam: Elsevier, Customer Service Department, PO Box 211 , 1000 AE Amsterdam, The Netherlands; phone: (+31) (20) 4853757; fax: (+31) (20) 4853432; e-mail: JournalsCustomerServiceEMEA@ elsevier.com

Tokyo: Elsevier, Customer Service Department, 4F HigashiAzabu, 1-Chome Bldg, 1-9-15 Higashi-Azabu, Minato-ku, Tokyo 106-0044, Japan; phone: (+81) (3) 55615037 ; fax: (+81) (3) 5561 5047; e-mail: JournalsCustomerServiceJapan@elsevier. com

Singapore: Elsevier, Customer Service Department, 3 Killiney Road, \#08-01 Winsland House I, Singapore 239519; phone: (+65) 63490222; fax: (+65) 67331510; e-mail: JournalsCustomerServiceAPAC@ elsevier.com

USA mailing notice: Homeopathy (ISSN 1475-4916) is published quarterly by Elsevier Ltd (The Boulevard, Langford Lane, Kidlington, Oxford OX5 1GB, UK). Periodical postage paid at Rahway $\mathrm{NJ}$ and additional mailing offices.

USA POSTMASTER: Send change of address: Homeopathy, Elsevier, 6277 Sea Harbor Drive, Orlando, FL 32887-4800.

AIRFREIGHT AND MAILING in USA by Mercury International Limited, 365, Blair Road, Avenel, NJ 07001.

Publication information: Homeopathy (ISSN 1475-4916). For 2008, volume 97 is scheduled for publication. Subscription prices are available upon request from the Publisher or from the Regional Sales Office nearest you or from this journal's website (http://www.elsevier.com/locate/homp). Further information is available on this journal and other Elsevier products through Elsevier's website: (http://www.elsevier.com). Subscriptions are accepted on a prepaid basis only and are entered on a calendar year basis. Issues are sent by standard mail (surface within Europe, air delivery outside Europe). Priority rates are available upon request. Claims for missing issues should be made within six months of the date of dispatch.

\section{Author enquiries}

For enquiries relating to the submission of articles (including electronic submission) please visit the journal's home page at http://www.elsevier.com/locate/homp. You can track accepted articles at http://www.elsevier.com/trackarticle and set up e-mail alerts to inform you of when an article's status has changed, as well as copyright information, frequently asked questions and more.

Contact details for questions arising after acceptance of an article, especially those relating to proofs, are provided after registration of an article for publication.

\section{Advertising, Reprints or Supplements}

Contact:

Bethan Keall

Therapy Sales Manager

Elsevier Ltd

32 Jamestown Road

London NW17BY

Tel: $+44(0) 2074244280$

E-mail: b.keall@elsevier.com

\section{Publisher}

Elsevier Ltd

The Boulevard

Langford Lane

Kidlington

Oxford OX5 1GB

Tel: +44 (0)1865 843824

Fax: +44 (0)1865 843997

Visit our website: www.elsevier.com/locate/homp 


\section{The Journal of the Faculty of Homeopathy Volume 97, Number 3, July 2008}

\section{Guest Editorial}

The electrical properties of high dilutions

C.W. Smith

\section{Announcement}

New Member of our International Advisory Board

\section{Original Papers}

Towards standard setting for patient-reported outcomes in the NHS homeopathic hospitals

E.A. Thompson, R.T. Mathie, E.S. Baitson, S.J. Barron, S.R. Berkovitz, M. Brands, P. Fisher, T.M. Kirby,

R.W. Leckridge, S.W. Mercer, H.J. Nielsen, D.H.K. Ratsey, D. Reilly, H. Roniger and T.E. Whitmarsh

Homeopathy and systematics: a systematic analysis of the therapeutic effects of the plant species used

in homeopathy

V. Bharatan

Electrical impedance and HV plasma images of high dilutions of sodium chloride

R. Assumpção

Delayed luminescence of high homeopathic potencies on sugar globuli

K. Lenger, R.P. Bajpai and M. Drexel

An animal model for the study of Chamomilla in stress and depression: pilot study

S.A. Gordinho Pinto, E. Bohland, C. de Paula Coelho, M.S. Furquim de Azevedo Morgulis and L.V. Bonamin

Effect of homeopathic medicines on helminth parasitism and resistance of Haemonchus contortus infected sheep

F. Zacharias, J.E. Guimarães, R.R. Araújo, M.A.O. Almeida, M.C.C. Ayres, M.E. Bavia and F.W. Mendonça-Lima

\section{Debate}

'Homeopathy': Untangling the debate

C. Relton, A. O'Cathain and K.J. Thomas

Social and Historical

Believing in order to understand: Hahnemann's hierarchisation of values

J.M. Schmidt

20 years ago: The British Homoeopathic Journal, July 1988

S.T. Land

Obituary

Dr J Dickson Mabon

P. Fisher

\section{Corrigendum}

Corrigendum to: Weber S, Endler PC, Welles SU et al. The effect of homeopathically prepared thyroxine on highland frogs. Homeopathy 2008; 97: 3-9

P.C. Endler

Forthcoming Meetings

Instructions to Authors 


\title{
Believing in order to understand: Hahnemann's hierarchisation of values ${ }^{\text {th }}$
}

\author{
JM Schmidt* \\ Department of the History of Medicine, University of Munich, Germany
}

\begin{abstract}
During the last 200 years, the social, scientific, and religious framework in which homeopathy is taught and practiced has changed tremendously. Various different forms of homeopathy have been advocated. To avoid being misled by the prevailing pluralism as a standard of reference for assessing new concepts, Hahnemann's original ideas and attitude toward medicine, philosophy, and ethics are discussed.

Hahnemann's hierarchisation of values appears to consist primarily in striving for a world view in which he could conceive of himself as a spiritual and moral being, secondly in a yearning for scientific advancement, and thirdly in his need to earn a living. Homeopaths are challenged to match this hierarchisation and be aware that homeopathy comprises dimensions other than just science and economics. Homeopathy (2008) 97, 156-160.
\end{abstract}

Keywords: Hahnemann; Homeopathy; Philosophy; Ethics; Credo ut intelligam

\section{Introduction}

One of the main issues in recent debates about homeopathy is the question of whether it should be considered a science or not. While the critics' view amounts to a denial of homeopathy being part of scientific medicine, its protagonists claim that homeopathy indeed fulfills the criteria of the scientific method, but that its application to the art of healing diseases requires a modification of approach, methodology, or paradigm. Accordingly, in order to demonstrate their compliance and compatibility with scientific standards, some homeopaths have adopted modern tools developed in and for mainstream medicine such as randomized clinical trials, quality assurance, evidence based medicine, etc. It seems that homeopathy today is conceived by its proponents mainly along these lines, as if it were nothing but a branch or specialty of modern scientific medicine.

However, considering that homeopathy evolved before the scientific method broke into clinical medicine on a large scale in the 19th century, it maybe worthwhile to recall its origins, which cannot be grasped with scientific categories alone. If it turns out that homeopathy as conceived by

*Correspondence: Josef M. Schmidt, Institut für Geschichte der Medizin, Ludwig-Maximilians-Universität München, Lessingstr. 2, 80336 München, Germany.

E-mail: j.m.schmidt@Irz.uni-muenchen.de

${ }^{2}$ Revised version of a paper presented at the 62nd Congress of the Liga Medicorum Homoeopathica Internationalis in Puebla, México, on 10 August 2007.

Received 31 October 2007; revised 26 March 2008; accepted 12 May 2008
Hahnemann has spiritual and moral as well as rationalistic and empirical roots, this would impact not only on the theory, practice, and status of homeopathy, but also on homeopaths' identity, the way they see themselves - in contrast to colleagues of other medical fields. Eventually, a deeper and broader understanding of what homeopathy is may even inspire efforts to remodel medicine at large in a more holistic, non-reductionistic way.

If homeopathy is more than an applied natural science with the object of medical treatment of diseases, how can we become aware of its other layers and dimensions? A short historical retrospect may convey a first impression of the changing and controversial interpretations of what homeopathy stands for.

\section{Homeopathy in changing times}

The notion "homeopathic', meaning "similar suffering", emerged for the first time in 1807, when Samuel Hahnemann coined the term to define the new method of rational therapeutics which he had recently suggested to his medical colleagues. ${ }^{1}$ Thus, homeopathy became an entity on its own, distinguished from any other concept of medicine and defined by characteristic basic principles. The "new school" of medicine spread around the globe, under very different regional and cultural conditions. From the beginning, however, there were issues of principle which were never fully resolved. Since the first major dispute between Hahnemann and some homeopaths, including 
Moritz Mueller, Traugott Kretzschmar and others about the limits of the principle of similars in the 1830s, there has been no clear and lasting consensus within the homeopathic community as to what homeopathy really is.

Despite a general agreement on Hahnemann's "Organon of Medicine" as the ultimate reference, ${ }^{2}$ there is great diversity of interpretation by modern homeopaths. ${ }^{3}$ Since the days of Hahnemann the face of homeopathy has changed from generation to generation. Given increasingly rapid succession of new approaches in recent decades, the latest state of the discussion about what should be considered homeopathy cannot be checked in traditional textbooks but in recently published articles or on the Internet. ${ }^{4}$

From a historical perspective, any change of approach or paradigm within homeopathy occurs in close interaction with concurrent changes of social, scientific, and religious conditions. For example, in a postmodern, pluralistic civilization of the 21 st century, it seems perfectly plausible to utilize concepts of quantum physics or chaos theory as models for an explanation of homeopathy, to apply computer repertorization and video supervision as tools for practice and education, and to resort to psychoanalytic concepts to understand the course of disease.

However, what any generation identifies as the essence of homeopathy tells us more about the mentality and values of the respective era or location than about what Hahnemann had in mind when he proclaimed homeopathy as a rational and charitable therapeutics. In order not to lose contact with its proper original roots, it maybe worthwhile to recall what Hahnemann really wanted.

\section{Hahnemann's world}

There is no problem in localizing Hahnemann's sphere of activity. He worked in some 25 towns and cities in modern Germany, Austria, Romania, and France. From the time in which he lived, however, we are separated not only by two centuries on a linear time-axis, usually imagined as a line of economic, social, scientific, and technological progress, but rather by different "worlds". To put oneself into Hahnemann's position one must subtract from our present knowledge all the milestones and achievements of modern medicine and, which is more difficult, go back to the time before the establishment of present so-called Western values.

Contrary to the widespread materialism, atheism, and hedonism of modern Western consumer societies, the leading ideas of Hahnemann's world were oriented to the spiritual and moral vocation of man. For Hahnemann humans were the noblest beings and created to perfect their emotional, practical, and mental capabilities, and, in so doing, honor God. In this he did not strikingly differ from many cultivated contemporaries. Nevertheless, from his biography it is clear that his aspiration for higher things was not just opportunistic lip service but a constant factor, which determined his life and work and to which he adhered faithfully. ${ }^{5}$

This strong interest in a spiritual and moral life apparently took first place in Hahnemann's mind and soul and must have been one of the vital impulses for the founding and development of homeopathy. This innocent-seeming state- ment gains explosive relevance if one considers under what circumstances today people try to justify homeopathy. In Hahnemann's day it was still possible for an educated man to outline a method of therapeutics (or even the new modern science which was emerging at that time) in a way that it was compatible with a good, moral, and fulfilled life. With such a claim, at the time of the Enlightenment, German idealism, and romanticism, one was in best philosophical company. The typical question of philosophers of nature at that time, such as Schelling, was: How must nature, spirit, matter, the organic and inorganic, etc. be thought (constructed) in order to - on the one hand unravel the relation of these notions and, on the other hand, enable to conceive of oneself as a moral and spiritual being?

The starting point was clearly the interest of mind and soul in an intelligible and moral world. The goal was a theory of science or, in Hahnemann's case, the founding of a rational system of therapeutics whose framework was defined by these fundamental considerations.

Today the proportion seems to be just the other way round. Fundamental today is:

- the definition of modern science which dominates faculties of medicine,

- the entanglement of scientific medicine with the pharmaceutical and other high-tech industries,

- the powerful structures of the medical profession and health insurance,

government policies aimed at reducing costs and increasing efficiency of health care etc.

Is it possible to live, within such a framework, a fair, moral and fulfilled life and to find a niche in the system where homeopathy can exist? The question today seems to be: What do I have to do, how do I have to practice, what do I have to demonstrate, in order to be recognized or at least tolerated by the existing institutions? In such socio-political circumstances, homeopaths strive to prove the efficacy of homeopathic medicines against placebo in compliance with pharmacological standards, to outline scientifically plausible hypotheses for the efficacy of ultramolecular dilutions, to document cost reduction with homeopathic treatment, to define the bounds of homeopathy to guard against charges of malpractice, etc.

It seems that the struggle for adaptation to the status quo and the meeting of socio-political demands today has taken the same (high) status in homeopaths' inner hierarchisation of values that educated men formerly gave to the creation of a well-ordered spiritual world. Some examples from the development of homeopathy may illustrate this point. ${ }^{6}$

\section{Hahnemann's doctrine}

Today it seems clear that incurable diseases exist. Any person who has such a disease, has bad luck and no chance. Hope for healing is obviously useless, stupid, and naive. Within present day's horizon this view appears obvious, evidence based, and verified in practice.

Hahnemann, however, was still able to argue theologically - that incurable diseases cannot exist! To maintain 
such an infidel statement, he said, would be blasphemy! With the same certainty, he argued, that there is a wise and kind God there must also be a remedy for each disease! It is for the doctor to find it in each case. So strong was Hahnemann's interest in a world in which he could realize himself as a moral and intelligent physician that he - as he put it - "rather would forswear all medical systems than allow this blasphemy to happen".?

Hahnemann's semiotic approach to drug provings and case taking is based on the same argument. A modern scientifically educated physician may agree that after the application of a substance in a drug proving on a healthy person certain symptoms occur, and that a given patient has similar symptoms. However, it would be difficult for him to explain why this similarity ought to be the reason that the substance heals the patient. Homeopaths try to identify causal mechanisms or refer to empirical clinical studies which, however, usually do not satisfy the critics. Ultimately, also homeopaths are discontented with such proof. They apply something practically which they are unable to explain theoretically, to themselves or others.

Hahnemann, however, had other inner preferences. Higher than his drive to seek explanations of his experiences was his impetus to found a therapeutics in which it was possible to heal with certainty. For him, this was the precondition of medical practice as a moral and spiritual being. Otherwise, he would rather have persevered with forensic medicine, chemistry or writing, as he did for many years before he founded homeopathy.

At this critical point Hahnemann argued theologically: First, from God's love and reason it follows that a reliable therapeutics must exist. And second, since often neither causes of diseases nor active agents of drugs are discernible, this knowledge cannot be necessary to cure diseases. From these premises it ensues that it must be possible to cure patients exclusively by means of the perceptible: the symptoms of patients and of healthy provers. Hence, diseases have to reveal themselves to those who can see in the symptoms of the disease, while the therapeutic power of substances reveal themselves in the symptoms of the proving.

According to this logic, the principle of similars indeed appears to be the only possible rational and reliable principle of healing. Hahnemann's main concern was thus fulfilled, any further details were minor problems. This does not mean that Hahnemann's homeopathy was nothing but a despairing construction of a quaint aesthete, nor that today's scientific medicine grasps true reality. Both approaches, the homeopathic and the scientific, are projects of honorable physicians, motivated mostly by noble intentions. Neither is absolutely wrong, nor absolutely right. Neither the one nor the other is favored and practised by good or bad people only. The difference rather lies in a small distinction which has large consequences. It is the hierarchisation of the motives which lead to the constitution of a specific healing system.

\section{Philosophical perspectives}

At this point it becomes clear that comprehending homeopathy does not only imply medical and historical, but also philosophical perspectives. At the philosophical level one can explore which model of life (or model of therapeutics) makes what sense and costs what price; or which attitudes and aims are more or less suitable to a good life. Neither the nature of man nor the meaning of life is neutral, independent qualities outside the observer. Since we can never face ourselves objectively but rather are always amidst it, in our own life, we have the freedom to change, by small self-enacted shifts, our whole life. We all know the gigantic effects on our life of ideologies or rethinking processes such as logical positivism, capitalism, socialism, emancipation, ecology, etc.

In the realm of philosophy, however, opinions are divided. Yet, despite the dependence on time and site of spiritual movements, in all epochs two main philosophies can be identified: the materialistic and the idealistic. Accordingly, Plato spoke of the "gigantomachía perí tes ousías" (the huge fight about being/essence) among those who wish to explain everything bottom-up or top-down, respectively. ${ }^{8}$ As Fichte said: "What philosophy one chooses depends on what kind of human one is" - referring to the basic distinction between dogmatism and idealism. ${ }^{9}$ Hence, it is as important to bear in mind Hahnemann's internal dimension, as the external conditions under which he lived and struggled.

Since a philosopher can be understood only when one understands his basic question, the key to a deep understanding of Hahnemann's homeopathy could be his over-riding concern which can be reconstructed approximately as: How is a therapeutics possible which on the one hand permits real cures and on the other hand enables the doctor to conceive of himself as a moral and spiritual being?

Modern science-oriented medicine, however, comes from an almost diametrically opposite tradition. Since the $17^{\text {th }}$ century, the predominating question of science and industry is: How can nature be commanded and dominated most certainly and effectively? Since the time of Francis Bacon, scientists and engineers have tried to wrest from nature its secrets with screws and clamps. The results gained, however, tell more about the questioner than about the questioned.

Hahnemann stood at an intersection of conflicting trends. On the one hand, he advocated - especially in his early days - a kind of scientific positivism which made him hope to elevate therapeutics from its status as a "conjectural art" to the rank of a reliable science. On the other hand, in his religious creed still lingered the traditional humility with regard to the possibility of human knowledge: "Credo, ut intelligam" (I believe in order to understand, Anselm of Canterbury, 1033-1109). ${ }^{10}$ Hahnemann frankly admitted for instance that he "did not understand" the surprisingly long-lasting effects of high potencies (30c). ${ }^{11}$ Although, whenever possible, he "dared to know" (aude sapere), the avowal of ignorance in this case was not the worst case for him. Much worse would have been the impossibility in principle of a therapeutics in which he could practice successfully and at the same time be a moral and spiritual being.

\section{Hahnemann's view of man}

Since homeopathy for Hahnemann implied philosophical dimensions, detached from the spiritual and mental 
background of its founder, only parts of his homeopathy can be grasped. The most important connecting links or the reconciling spiritual ties were missing. A therapeutics which, for instance, uses artificial electromagnetic fields to modify alleged electromagnetic fields of the patient, would not be homeopathy in the sense of Hahnemann, even if the fields were similar!

Hahnemann's homeopathy was founded before the definitive reification of man as a material, biochemical, molecular-biological, cybernetic, quantum-mechanical, or other reductionistic thing. This is the big difficulty when homeopathy's integration in the scientific mainstream is attempted. On the other hand, it is also a major opportunity to call to mind what mainstream medicine has lost during the last two centuries. In Hahnemann's cosmos of ideas, humans still had an internal dimension which was not considered a mere epiphenomenon of neuronal currents in brain cells. To Hahnemann rationality never meant logical sterility but always the inclusion of this inner source of human life. It would have struck him as being most irrational to consider man as entirely explicable by science.

The reification of man, which in science is inevitable, becomes problematic when generalized into a world picture or view of life: a provisional limitation of one's own horizon for the purpose of solution of a specific problem may turn into a global view of man and universe. Philosophically, it makes a huge difference whether, for methodological reasons, I confine my perception, cognition, and language to physical entities and mathematical laws and try to explain as many parts and aspects of the world as possible, on the basis of theses categories, or whether I maintain that the whole world consists of nothing but physical entities and mathematical laws. Because of this naturalistic fallacy most people today simply believe that modern scientific theories and hypotheses such as the big bang theory, the theory of evolution, selfish genes etc. are first-hand descriptions of objective reality.

However, once one has removed from life everything but matter and so-called natural laws, leaving nothing but hard facts and data, it may become impossible to give any reason for ethical behavior, because from "what is" does not follow "what should be". On the other hand, when one recognizes dimensions such as subjectivity, destination, God, spirit, mind, etc. and their vectorial (intentional) constitution, there may be a base for ethics.

The recognition of the inner dimension and vocation of man, which for Hahnemann was a matter of course, today seems more difficult, but no less important. It is an act of freedom but not arbitrary. It should acknowledge a certain constitution of man, not assume it from the outset (as suggested in constructivism). In this way, it could restore to man the wealth of his capacities which are increasingly contested by the triumphant advances of modern science. This should not only to be understood as an act of pure kindness.

Considering the potential dangers of a medicine exclusively based on modern science, manifesting in iatrogenic illnesses, allergies, addictions and deaths, a revision or widening of the narrow scientific view of man has become an ecological task of the first order. ${ }^{12}$

\section{Discussion}

Starting from the question "Is homeopathy a science?", this investigation of the roots of Hahnemann's homeopathy has arrived at perennial issues of philosophy, anthropology, and ethics. At first sight, this may come as a surprise. But if homeopathy were really well defined and had a firm place in the systematics of science or history of medicine, it would probably have been labeled, put into a drawer, and been long since forgotten. One single "crucial experiment" would have sufficed to either discard it for good or to accept and integrate it into mainstream medicine.

But since homeopathy ramifies through many disciplines and many dimensions of human life, it remains a challenge to reflect on the connection of these seemingly disparate spheres. By compelling oneself to go back beyond the last two centuries of our history of medicine and science, engagement with homeopathy thus offers a rare chance to become acquainted with the, in some respects totally different, world of a prominent physician of those days, from within. If we succeed in transforming its essence and characteristics back into our times, it might broaden our horizon, increase our options, and open up new potential for shaping homeopathy in the future.

If we acknowledge, for instance, that designing a therapeutics in which one can feel at ease spiritually and mentally is as legitimate as curing diseases, we would probably assess the dogmas set up by Hahnemann in a milder light. It has been suggested that all the parts of the homeopathic framework where Hahnemann argued theologically strike the modern reader as dogmatic. Besides the principle of similars this applies to the semiotics of disease symptoms and proving symptoms or to his strict ban of allopathic supplementary therapies and other issues. The condemnation by Hahnemann of the Leipzig "bastard homeopaths" due to their "unhomeopathic crimes" displayed the religious zeal of an indignant soul defending inviolable principles. ${ }^{13}$

But other cornerstones of the homeopathic doctrine were established under less dramatic conditions, rather out of strategic consideration, and Hahnemann could be flexible and pragmatic, for instance in his directions regarding single remedies (instead of double remedies) or his interpretation of the treatment of cholera with Camphor as homeopathic instead of antiseptic.

Considering Hahnemann's original interests not only facilitates a better understanding of his uncompromising rigidity on some matters but also of his continuous changes concerning posology. Since questions about doses and potencies, from his point of view, were problems to be solved empirically and had no consequences of principle to his doctrine, there was little he would not modify to discover the optimum, including the ratio of dilution, number of strokes, interval between prescriptions, degree of potencies, ascending or descending scales, etc.

This can, in addition, help us to elaborate a new criterion for the assessment of who is a genuine homeopath in the Hahnemannian sense. When in a doctor's inner hierarchisation the urge to outline, sustain, and defend a view of life 
which allows the physician to conceive himself as a spiritual and moral being takes the first place, he might be considered as belonging to the inner circle of true Hahnemannians. Of course, today many scientific considerations have to be taken into account other than those known to Hahnemann.

Hahnemann's yearning for scientific insights was strong, but in his inner hierarchisation it may have ranked in second place. Even the necessity of supporting himself and his large family, certainly a powerful motive for his untiring activity, followed in a third place at best. The hierarchisation here suggested of the main driving forces of Hahnemann may furthermore allow a somewhat unorthodox and unexpected assessment of the advocates of modern schools of homeopathy. The crucial question would be: Do they really match with Hahnemann's inner hierarchisation or are his second and third priorities their first?

In debate with mainstream medicine it should be remembered that for Hahnemann science was not everything. When faith or credulity in science starts to blind people to other important dimensions of life (e.g. spirituality and morality) and seduces them to the arrogant delusion of being masters and owners of the universe, Hahnemann would object. He sensed the dialectics between scientific cognition and anthropological views. The bigger and more impudent we estimate the capacities of science to know and command nature, the smaller and more onedimensional the human looks, and the less important and meaningful becomes his individual life. Accordingly, for Hahnemann an attitude of awe and self-discipline intensified quality of life rather than impairing it. Today, however, scientists try to measure and optimize it by means of biometrical analysis and technical intervention, instead of looking for where it was lost in the first place.

Obviously, it is convenient to have computer repertories, video data banks, meta-analyses of clinical trials, competition for excellence, and theories inspired by quantum mechanics or psychotherapy, etc. It signifies scientific progress and economic rationalization. For Hahnemannians, however, the question remains: What kind of world do we create when we continue to follow this path uncritically? Do we really want to conceive ourselves, for instance, as a concentric cone whose plane of vibration is shifted by contact with a pellet of saccharose? Or as a conglomerate of delusions from which we will never be liberated entirely and behind which lurks nothingness?

It seems that homeopaths of Western industrialized countries may in fact, and contrary to modernistic mainstream doctors, consider themselves fortunate in having preserved Hahnemann as a perennial reference point, lighthouse, or even paradigm of a well-balanced attitude toward the basic questions of life. To be sure, Hahnemann appreciated and applied science and economics in his life and practice. But as he saw it, they had a subordinate status rather than being everything.

\section{References}

1 Hahnemann S. Gesammelte kleine Schriften. Herausgegeben von Josef M. Schmidt und Daniel Kaiser. Heidelberg: Haug, 2001, pp 460-472.

2 Hahnemann S. Organon der Heilkunst. Neufassung der 6. Auflage mit Systematik und Glossar von Josef M. Schmidt. München: Elsevier, 2003.

3 Schmidt JM. Taschenatlas Homöopathie in Wort und Bild. Grundlagen, Methodik und Geschichte. Heidelberg: Haug, 2001.

4 www.grundlagen-praxis.de. International Discussion.

5 Schmidt JM. Die philosophischen Vorstellungen Samuel Hahnemanns bei der Begründung der Homöopathie. München: Sonntag, 1990.

6 Schmidt JM. Homöopathie im Jahre 250 nach Hahnemann. Naturheilpraxis 2005; 58: 1738-1744.

7 Hahnemann S. Gesammelte kleine Schriften. Herausgegeben von Josef M. Schmidt und Daniel Kaiser. Heidelberg: Haug, 2001. p 493.

8 Plato. Sophistes, 246a. In: Platonis Opera. Burnet Ioannes (ed). Vol. 1, Oxford: Oxford University Press, 1979, p 404.

9 Fichte JG. Erste Einleitung in die Wissenschaftslehre. Philos J 1797; 5: $1-47$.

10 Anselm of Canterbury. Proslogion, 1. See also Augustinus. De vera religione; 5: 24 .

11 Hahnemann S. Die chronischen Krankheiten, ihre eigenthümliche Natur und homöopathische Heilung. 1. Theil, 2. Auflage. Dresden und Leipzig: Arnold, 1835, p 154.

12 Schmidt JM. Anthropology and medicine. The image of man in different therapeutic approaches. $B r$ Homeopath $J$ 1993; 82: 288-296.

13 Hahnemann S. Gesammelte kleine Schriften. Herausgegeben von Josef M. Schmidt und Daniel Kaiser. Heidelberg: Haug, 2001, pp 836-839, here 837. 


\title{
ERRATUM
}

\section{Erratum to "Believing in order to understand: Hahnemann"s hierarchisation of values" [Homeopathy 97(2008) 156-160]}

\author{
JM Schmidt* \\ Department of the History of Medicine, University of Munich, Germany
}

It is with regret that on p. 157 the text that appears:

The typical question of philosophers of nature at that time, such as Schelling, was: How must nature, spirit, matter, the organic and inorganic, etc. be thought (constructed) in order to - on the one hand unravel the relation of these notions and, on the other hand, enable none to conceive of oneself as a moral and spiritual being?

Should have read:

The typical question of philosophers of nature at that time, such as Schelling, was: How must nature, spirit, matter, the organic and inorganic, etc. be thought (constructed) in order to - on the one hand unravel the relation of these notions and, on the other hand, enable one to conceive of oneself as a moral and spiritual being?

Replacing the "none" with "one". 